\title{
Breaking Bad Customs: Involving the Idea of Opinio Juris Communis in Asian State Practice
}

\author{
Thamil Venthan Ananthavinayagan*
}

\section{Introduction: The Formation of Customary International Law}

Customary International Law (CIL) is one of the sources of Article 38.1 of the International Court of Justice (ICJ) Statute, consisting of two elements, namely state practice as its objective element, and the belief in such state practice as its subjective element. ${ }^{1}$ An action forms custom only if it can formulate the articulation of the legality of the action. ${ }^{2}$ Opinio juris is considered to be statements of belief, but not actual beliefs. Against this background, treaties and declarations that represent opinio juris are considered to be statements about the legality of action, rather than examples of that action. ${ }^{3}$ However, Posner and Goldsmith claim that:

It lacks a centralized law-maker, a centralized executive enforcer, and a centralized, authoritative decisionmaker. The content of CIL seems to track the interests of powerful nations. The origins of CIL rules are not understood. We do not know why nations comply with CIL, or even what it means for a nation to comply with CIL. And we lack an explanation for the many changes in CIL rules over time. ${ }^{4}$

Surely, CIL can be considered a last resort in disputes over international law. When there is no applicable legally-binding treaty, it is always possible to

* Lecturer in International Law at Griffith College, Dublin, Ireland.

1 Zhang Yue, Customary International Law and the Rule Against Taking Cultural Property as Spoils of War, 17 Chinese Journal of International LAW 943, 947 (2018).

2 Anthea Elizabeth Roberts, Traditional and Modern Approaches to Customary International Law: A Reconciliation, 95 The American Journal of International Law 757, 758 (2001).

3 Anthony D'Amato, The Concept of Special Custom in International Law, 63 American Journal of International LaW 211, 214 n. 14 (1969) (citing Francois Francois Geny, Methode D'interpretation et Sources en Droit Prive Positif (2nd ed. 1919)).

4 Eric A. Posner \& Jack L. Goldsmith, A Theory of Customary International Law, 66 Unive RSITY of Chicago LaW Review 1113, 1114 (1999). 
argue that a certain rule has crystallised within CIL. However, it is a rather complicated task to prove the existence of a customary rule because to do so requires strong evidence of the existence of two fundamental elements. When this source of law was formed, the vast majority of the states that exist today were inexistent due to economic conditions and the structure of social relations. ${ }^{5}$ In consequence, these newly formed states criticise or reject the norms under CIL, while not refuting public international law in general. ${ }^{6}$ And yet, despite the acceleration of actors under international law, "Western developed countries have continued to construct and reconstruct the norms of international law in their favour to the detriment of the third-world countries". The Third World Approaches to International Law (TWAIL) wishes, to this end, to dismantle the prevailing norms that benefit the powerful few. B.S. Chimni suggests that TWAIL gives meaning to international law, as it transforms it into international law of emancipation and reshapes international law as international legal norms that offer a life of dignity for the poor, deprived, oppressed and subjugated in the Third World. ${ }^{8}$ The argument in this article is not that CIL is useless or solely a Western product, but it wishes to advance the idea that CIL needs to include and proliferate the subaltern voices to a greater extent.

To this end, the widespread and consistent practice is followed by the belief in it. Another aspect of this practice is its general practice. Regardless of localities and regional practices, a large share of affected states must be engaged in the practice. The density of practice required, however, is difficult to determine with precision. ${ }^{9}$ Moreover, there are genuine questions about the legitimacy of CIL. While treaties express promises in written forms, they foresee dispute resolution mechanisms engineered into the treaties for the signatories who are bound by them. In opposition to this, CIL is unwritten arising from decentralised practices of nations, while the criteria for its identification are unclear. ${ }^{10}$ Arteem Negev holds the view that:

5 See S. Prakash Sinha, New Nations and the International Custom, 9 William \& Mary LAW RevieW 788, 792 (1968).

$6 \quad$ Id.

7 Brian-Vincent Ikejiaku, International Law is Western Made Global Law: The Perception of Third-World Category, 6 African Journal of Legal Studies 337, 338 (2013).

8 B.S. Chimni, The Past, Present and Future of International Law: A Critical Third World Approach, 8 Melbourne Journal of International LaW 499, 499-50o (2007).

9 Andrew T. Guzman, Saving Customary International Law, 27 Michigan Journal of INTERNATIONAL LAW 115, 15 O (2005).

$10 \quad$ Posner \& Goldsmith, supra note 4, at 1116. 
CIL may not be legally legitimate because it can be too ambiguous, bypasses the requirement of tacit consent, and breaches the principle of sovereign equality of states. However, CIL is morally legitimate due to the benefits it provides for international law. The moral value of CIL lies in its ability to be widespread, avoid withdrawal from obligations, and fill in gaps in international law. Lastly, CIL is socially legitimate because it is de facto accepted by the international community. ${ }^{11}$

Anthony D'Amato and others have pointed out that CIL creates law based on which it requires action in conscious accordance with law preexisting the action. This practice requirement of CIL needs more scrutiny, as more efforts need to be put into the investigation of the creation of custom and its consistency. ${ }^{12}$ What does, however, consistency mean? In the North Sea Continental Shelf Sea case, Judge Lachs from the ICJ postulated:

What can be required is that the party relying on an alleged general rule must prove that the rule invoked is part of a general practice accepted as law by the States in question. No further or more rigid form of evidence could or should be required.

In sum, the general practice of States should be recognized as prima facie evidence that it is accepted as law. Such evidence may, of course, be controverted - even on the test of practice itself, if it shows "much uncertainty and contradiction" ... It may also be controverted on the test of opinio juris with regard to "the States in question" or the parties to the case. ${ }^{13}$

A prominent theory explains the legitimacy as one which is understood as a rule with its institutional penumbra to have a high degree of legitimacy. Here, legitimacy is rooted in the rule-making institution and exertion of compliance on those addressed normatively. Those who are addressed believe in the rule or institution and operate in accordance with generally accepted principles of legitimate process. ${ }^{14}$

\footnotetext{
11 Artem Sergeev, The Legitimacy of Customary International Law: Legal, Moral, and Social Perspectives, 8 International Review of LaW 13 (2017).

12 D'Amato, supra note 3 , at 4.

13 North Sea Continental Shelf (Ger. v. Den.), 1969 I.C.J. 232 (Feb. 20) (dissenting opinion of Judge Lachs).

14 Thomas M. Franck, The Power of Legitimacy and the Legitimacy of Power: International Law in an Age of Power Disequilibrium, 100 The American Journal of International LAW 88, 93 (1990).
} 
CIL's doctrine is, in the end, "contradictory, inconsistent, indeterminate and informal". 15 To this end:

These characteristics are in some respects problematic, but they also create enough space to empower anyone invoking custom, whether in the First World or elsewhere, to pursue their own vision of the international rule of law. In other words, the fluidity and malleability of the doctrine allows the identification of custom to operate both as a tool of oppression by the First World and as empowerment of the periphery. ${ }^{16}$

However, can a custom born and developed in the Western Hemisphere extend to and dictate state practice of the states that were restricted in their governance? How can cultures, long neglected and disregarded in cultural evolutions, see themselves represented in the development of CIL? Shall these cultural and legal practices, instead, languish? B.S. Chimni, in his groundbreaking piece, explains that CIL reflects "the dominance or hegemony of certain [Western] ideas and beliefs" for which a Third World scout tries to assist in its promotion. ${ }^{17} \mathrm{He}$ further argues that CIL "safeguards the interests of the advanced capitalist nations even as it at times addresses the concerns of the entire international community", 18 while also "naturaliz[ing] and validat[ing]" certain Western assumptions and preferences. ${ }^{19}$ Ultimately, Chimni argues in favour of a postmodern doctrine that would overcome these shortcomings. The ICJ had taken into account the existence of regional customary law in the Asylum case ${ }^{20}$ and particularly in the Rights of Passage over Indian Territory case. ${ }^{21}$ Indigenous Asian laws continue to play an important role vis-à-vis Western law. Having postulated this, the article will examine the structural legal discussions in relation to the Preah Vihear case and the South China case.

\footnotetext{
15 Jean d'Aspremont, A Postmodernization of Customary International Law for the First World?, 112 AJIL Unbound 293, 295 (2018).

$16 \quad$ Id.

17 B.S. Chimni, Customary International Law: A Third World Perspective, 112 The AME RICAN SOCiETY OF InTERNATIONAL LAW 1, 28 (2018).

$18 \quad I d$. at 9 .

19 Id. at 28.

20 Asylum Case (Colom. v. Peru), Judgement, 1950 I.C.J. Rep. 266 (Nov. 20).

21 Case concerning Right of Passage over Indian Territory (Port. v. India), Judgement, 196o I.C.J. Rep. 6 (Apr. 12).
} 


\subsection{Case Studies from the Asian Region}

In the following two sections it is worthwhile to draw experiences on the development of CIL in the Asian region. To this end, the Preah Vihear case and the South China Sea dispute are relevant for consideration.

\subsubsection{Preah Vihear Case}

In 1904, a treaty between Cambodia and Thailand created a joint commission to demarcate their border according to a watershed, which placed the ancient Hindu temple of Preah Vihear in Thai territory. However, a 1907 map drawn by French authorities relocated the boundary without explanation, placing the temple squarely in Cambodian territory. The ICJ determined that both parties accepted the French map in 1908 as an "interpretation" of the treaty text: "the Parties at that time adopted an interpretation of the treaty settlement which caused the map line, in so far as it may have departed from the line of the watershed, to prevail over the relevant clause of the treaty". ${ }^{22}$ Even though the first judgment rendered in 1962 proved that Cambodia had sovereignty over the Temple of Preah-Vihear and its vicinity, due to heated situations along the borders that were threatening peace in that region and unsuccessful bilateral consensus, the ICJ was solicited again by both countries, in order to clear the misunderstandings that cropped up by interpreting the initial judgment again in 2013. Whilst the ICJ reached a decision in unanimity with its previous judgment, it can be noted that it relied greatly on the legal basis that the treaty claim asserted. ${ }^{23}$ Moreover, there are strong arguments for why, although Thailand never contested the French map's placement of the temple, it was inappropriate to describe its silence as an acceptance. ${ }^{24}$ While this issue might be addressed in the bilateral context by requiring a high threshold showing that a state's silence was knowing and intentional over an extended period of time, as is required for desuetude, it will be nearly impossible to be demonstrated in a multilateral treaty regime. As one commentator notes:

[T] he Temple of Preah Vihear case exhibits, international law in Asia seems to undermine its legitimacy by a wilful abdication of non-Western knowledge systems and practices, particularly those from the margins. Arguably, periphery and not centre should then construct the modern

22 Case concerning the Temple of Preah Vihear (Cambodia v. Thai.), Judgement, 1962 I.C.J. Rep. 6, 34 (June 15).

23 Solida Svay, Analysis of the Preah-Vihear Temple Case, Cambodia v/s Thailand at the International Court of Justice under Common Territorial Claims Involving Land Disputes, 36 Journal of Law, Policy And Globalization 12, 12 (2015).

24 Cambodia v. Thai., 1962 I.C.J. at 4. 
state. Such an untangling, even if politically brave, would prioritize the Siamese alternate-modern polity over colonial territorial conceptions of state. The conception of political spaces that Siam harboured does not only have an Asian application. Any revision of the international law of territory by conceptually displacing territory and planting people at its core in a world blinded by sovereignty-induced boundaries and territory is a knowledge production of universal application. ${ }^{25}$

Is it fair to assert that majority rulings by the Court are a general rule of CIL? Does this bind the rest of arbitrators involved? ${ }^{26}$ Moreover, can peoples from the Global South accept that their Third World elite, complicit in the extension of Western knowledge production within CIL, deprives them of their understanding of belonging, demarcations, culture and localities? In reality, it becomes evident that international law's potency is limited and disregards indigenous geographies, knowledge and customs at large. ${ }^{27}$

\subsubsection{South China Sea Dispute}

Being one of the most contested areas on our planet's surface due to fishing, shipping and presumed oil and gas resources, many incidents between China and the Philippines after 2011 led to unsuccessful bilateral consultations. ${ }^{28}$ Two options were at hand to settle the dispute: first, proceedings before the ICJ; second, compulsory jurisdiction under the United Nations Convention on the Law of the Sea (UNCLOS). The former option was not feasible, considering that China never accepted the compulsory jurisdiction of the Court, and the Philippines excluded the Court's jurisdiction for these kinds of disputes under Article 36.2 of the ICJ Statute. ${ }^{29}$

25 Life of Imperialism: Thailand, Territory and State Transformation, INSTITUTE FOR INTERNATiONAL LAW AND Justice, https://www.iilj.org/wp-content/uploads/2017/10/Semi SiamSINGH.pdf (last visited Oct. 20, 2019).

26 Kaiyan Homi Kaikobad, Nullity and Validity: Challenges to Territorial and Boundary Judgements and Awards, in Asian Approaches to International LaW and the Legacy of Colonialism 45, 49 (Jin-Hyun Paik et al. eds., 2014).

27 See Prabhakar Singh, Of International Law, Semi-colonial Thailand, and Imperial Ghosts, 9 Asian Journal of International LaW 46, 68 (2019).

28 Andreas Zimmermann \& Jelena Bäumler, Navigating Through Narrow Jurisdictional Straits: The Philippines - PRC South China Sea Dispute and UNCLOS, in 12 THE LAW \& PRActice of INTERNational Courts and TRIBunals 431, 432 (2013).

29 See Secretary of Foreign Affairs of Republic of the Philippines, Declarations Recognizing the Jurisdiction of the Court as Compulsory, International Court of Justice (Jan. 18, 1972), http://www.icj-cij.org/en/declarations/ph. Also, it would have been unlikely that 
Hence, the only resort was the UNCLOS. As of now, all countries bordering the South China Sea are states parties to the UNCLOS, including China and the Philippines. ${ }^{30}$ Being states parties to the UNCLOS, they are subject to the dispute resolution provisions under part XV. The Philippines argued there were several disputes between the Philippines and China concerning the interpretation or application of the UNCLOS. ${ }^{31}$

China would have accepted an invitation of the Philippines to agree on the ICJ's jurisdiction under the concept of forum prorogatum, ICJ Statue Article 38.5.

30 U.N. Division for Ocean Affairs and the Law of the Sea, Chronological Lists of Ratifications of, Accessions and Successions to the Convention and the Related Agreements, http:// www.un.org/depts/los/reference_files/chronological_lists_of_ratifications.htm (last visited Oct. 20, 2019). The dates of ratification of the fiver concerned states are as follows: Brunei Darussalam, November 5, 1996; China, June 7, 1996; Malaysia, October 14, 1996; the Philippines, May 8, 1984; and Vietnam, July 25, 1994.

31 In the Matter of the South China Sea Arbitration (Phil. v. China), Case No. 2013-19, II 112 (Perm. Ct. Arb. 2016), https://www.pcacases.com/pcadocs/PH-CN\%2O-\%2O20160712\%20 -\%20Award.pdf [hereinafter South China Sea Arbitration]; Division for Ocean Affairs and the Law of the Sea Office of Legal Affairs, 2017 Law of the Sea Bulletin 91, https://doi.org/ 10.18356/66155955-en. These dispute submissions were:

(1) China's maritime entitlements in the South China Sea, like those of the Philippines, may not extend beyond those expressly permitted by the United Nations Convention on the Law of the Sea;

(2) China's claims to sovereign rights jurisdiction, and to "historic rights", with respect to the maritime areas of the South China Sea encompassed by the so-called "ninedash line" are contrary to the Convention and without lawful effect to the extent that they exceed the geographic and substantive limits of China's maritime entitlements expressly permitted by UNCLOS;

(3) Scarborough Shoal generates no entitlement to an exclusive economic zone or continental shelf;

(4) Mischief Reef, Second Thomas Shoal, and Subi Reef are low-tide elevations that do not generate entitlement to a territorial sea, exclusive economic zone or continental shelf, and are not features that are capable of appropriation by occupation or otherwise;

(5) Mischief Reef and Second Thomas Shoal are part of the exclusive economic zone and continental shelf of the Philippines;

(6) Gaven Reef and McKennan Reef (including Hughes Reef) are low-tide elevations that do not generate entitlement to a territorial sea, exclusive economic zone or continental shelf, but their low-water line may be used to determine the baseline from which the breadth of the territorial sea of Namyit and Sin Cowe, respectively, is measured;

(7) Johnson Reef, Cuarteron Reef and Fiery Cross Reef generate no entitlement to an exclusive economic zone or continental shelf;

(8) China has unlawfully interfered with the enjoyment and exercise of the sovereign rights of the Philippines with respect to the living and non-living resources of its exclusive economic zone and continental shelf; 
After initiation by the Philippines on the 22nd of January $2013,{ }^{32}$ a tribunal was constituted under Annex VII to the UNCLOS and delivered its award on the 12th of July 2016. This award followed an earlier Award on Jurisdiction and Admissibility dating from the 29th of October 2015. In the award of the 12th of July 2016, the Arbitral Tribunal decided as follows:

(9) China has unlawfully failed to prevent its nationals and vessels from exploiting the living resources in the exclusive economic zone of the Philippines;

(10) China has unlawfully prevented Philippine fishermen from pursuing their livelihoods by interfering with traditional fishing activities at Scarborough Shoal;

(11) China has violated its obligations under the Convention to protect and preserve the marine environment at Scarborough Shoal, Second Thomas Shoal, Cuarteron Reef, Fiery Cross Reef, Gaven Reef, Johnson Reef, Hughes Reef and Subi Reef;

(12) China's occupation of and construction activities on Mischief Reef

(a) violate the provisions of the Convention concerning artificial islands, installations and structures;

(b) violate China's duties to protect and preserve the marine environment under the Convention; and

(c) constitute unlawful acts of attempted appropriation in violation of the Convention;

(13) China has breached its obligations under the Convention by operating its law enforcement vessels in a dangerous manner, causing serious risk of collision to Philippine vessels navigating in the vicinity of Scarborough Shoal;

(14) Since the commencement of this arbitration in January 2013, China has unlawfully aggravated and extended the dispute by, among other things:

(a) interfering with the Philippines' rights of navigation in the waters at, and adjacent to, Second Thomas Shoal;

(b) preventing the rotation and resupply of Philippine personnel stationed at Second Thomas Shoal;

(c) endangering the health and well-being of Philippine personnel stationed at Second Thomas Shoal; and

(d) conducting dredging, artificial island-building and construction activities at Mischief Reef, Cuarteron Reef, Fiery Cross Reef, Gaven Reef, Johnson Reef, Hughes Reef and Subi Reef; and

(15) China shall respect the rights and freedoms of the Philippines under the Convention, shall comply with its duties under the Convention, including those relevant to the protection and preservation of the marine environment in the South China Sea, and shall exercise its rights and freedoms in the South China Sea with due regard to those of the Philippines under the Convention.

Dep't of Foreign Affairs of the Republic of the Phil., Notification and STATEMENT OF ClAims (2013), https://www.dfa.gov.ph/images/UNCLOS/Notification $\% 2$ oand \%2oStatement\%2oof\%2oClaim\%2oon\%2oWest\%2oPhilippine\%2oSea .pdf; Memorial of the Philippines, Arbitration under Annex viI of the Unclos (Phil. v. China), Vol. III, Annex 1 (Mar. 30. 2014), http://www.pcacases.com/pcadocs/The\%2O Philippines\%27\%2oMemorial\%20-\%2oVolume\%2oIII\%20\%28Annexes\%2O1-6o\% 29.pdf. 
1. China does not have historic maritime rights in the South China Sea (nine dash line)..$^{33}$

2. None of the disputed features in the South China Sea are islands (within the meaning of Article 121 of the UNCLOS) and thus do not trigger any rights in consistency with the UNCLOS. ${ }^{34}$

3. Chinese activities in the South China Sea violated Philippines' rights within their Exclusive Economic Zone. ${ }^{35}$

4. Chinese construction activities have caused damage to the natural environment. ${ }^{36}$

China, unsurprisingly, rejected the findings and refused to abide by them. Noteworthy is that China had submitted a declaration under Article 298 of the UNCLOS, excluding itself from compulsory jurisdiction. ${ }^{37}$ Most notably,

33 The nine-dash line is a cartographic denotation that was developed, first by the Republic of China in the 1940s, and then by the People's Republic of China (PRC) in the 1950s, and subsequent years to affirm Chinese sovereignty over the islands and maritime areas of the South China Sea.

34 Under Part VII UNCLOS, Article 121 distinguishes between islands and rocks as follows:

1. An island is a naturally formed area of land, surrounded by water, which is above water at high tide.

2. Except as provided for in paragraph 3, the territorial sea, the contiguous zone, the exclusive economic zone and the continental shelf of an island are determined in accordance with the provisions of this Convention applicable to other land territory.

3. Rocks which cannot sustain human habitation or economic life of their own shall have no exclusive economic zone or continental shelf.

35 The Exclusive Economic Zone (EEZ) is one of the major innovations in the law of the sea, Its legal regime are characterized as follows:

1. The EEZ is an area beyond and adjacent to the territorial sea: it can extend to a maximum 200 nautical miles from the baselines.

2. Within the EEZ, a coastal State enjoys sovereign rights over its natural resources. It can exercise its jurisdiction over certain activities for the purpose, among others, of protecting the environment. But it is also obliged to respect the rights of other States (thanks to the maintenance of certain freedoms laid down by the law of the high seas, such as freedom of navigation), to be found under Article 55 UNCLOS.

$36 \quad$ South China Sea Arbitration, supra note 31, If 983.

37 See U.N. Division for Ocean Affairs and the Law of the Sea, Declarations and Statements, http://www.un.org/depts/los/convention_agreements/convention_declarations.htm; see also Ministry of Foreign Affairs of the People's Republic of China, Position Paper of the Government of the People's Republic of China on the Matter of Jurisdiction in the South China Sea Arbitration Initiated By the RePUblic of THe PhilipPines, I 58 (2014), https://www.fmprc.gov.cn/nanhai/ eng/snhwtlcwj_1/tı368895.htm (Declaration of China in pursuant to Article 298: "The Government of the People's Republic of China does not accept any of the procedures provided for in section 2 of Part $\mathrm{XV}$ of the Convention with respect to all the categories of disputes referred to in paragraph 1 (a), (b) and (c) of Article 298 of the Convention"). 
China not only rejected the claims of the Philippines, but also rejected jurisdiction of the Tribunal with its position paper. ${ }^{38}$ Schoenbaum writes that "[t]he result of China's refusal to participate was a lawyer's dream - litigating a case before a court that will hear only one side of the case - his own". ${ }^{39}$ China has submitted a declaration under Article 298.1(a)(i) of the UNCLOS, excluding itself from compulsory dispute settlement under Article 287 and 288 of the UnCLOS. However, the existence of Article 9 Annex VII and Rule 25 of the Rules of Procedure is designed to prevent any adverse consequences imposed on a non-appearing party in proceedings. As noted, the non-appearing party is still a party to the case and is still bound by the decision of the tribunal whether it agrees with it or not - the famous Nicaragua-USA case before the ICJ is exemplary. ${ }^{40}$

$38 \quad I d$. 186 . Here, China provides that:

It is the view of China that the Arbitral Tribunal manifestly has no jurisdiction over this arbitration, unilaterally initiated by the Philippines, with regard to disputes between China and the Philippines in the South China Sea.

Firstly, the essence of the subject-matter of the arbitration is the territorial sovereignty over the relevant maritime features in the South China Sea, which is beyond the scope of the Convention and is consequently not concerned with the interpretation or application of the Convention.

Secondly, there is an agreement between China and the Philippines to settle their disputes in the South China Sea by negotiations, as embodied in bilateral instruments and the Doc. Thus the unilateral initiation of the present arbitration by the Philippines has clearly violated international law.

Thirdly, even assuming that the subject-matter of the arbitration did concern the interpretation or application of the Convention, it has been excluded by the 2006 declaration filed by China under Article 298 of the Convention, due to its being an integral part of the dispute of maritime delimitation between the two States.

Fourthly, China has never accepted any compulsory procedures of the Convention with regard to the Philippines' claims for arbitration. The Arbitral Tribunal shall fully respect the right of the States Parties to the Convention to choose the means of dispute settlement of their own accord, and exercise its competence to decide on its jurisdiction within the confines of the Convention. The initiation of the present arbitration by the Philippines is an abuse of the compulsory dispute settlement procedures under the Convention. There is a solid basis in international law for China's rejection of and nonparticipation in the present arbitration.

39 Thomas J. Schoenbaum, The South China Sea Arbitration Decision and a Plan for Peaceful Resolution of the Disputes, 47 Journal of Maritime LaW \& Commerce 451, 453 (2016).

40 Military and Paramilitary Activities in and against Nicaragua (Nicar. v. U.S.), 1986 I.C.J. Rep. 14, I 30 (June 27). Here the Court held: "[T] he Court cannot by its own enquiries entirely make up for the absence of one of the Parties; that absence, in a case of this kind involving extensive questions of fact, must necessarily limit the extent to which the Court is informed of the facts. It would furthermore be an over-simplification to conclude that the only detrimental consequence of the absence of a party is the lack of opportunity to 
China's argument was that the question of territorial sovereignty over certain islands and reefs did not fall within the ambit of the UnCLOS. ${ }^{41}$ When coming to the aspect of the nine-dash line, the Tribunal had to overcome this jurisdictional obstacle, and declared that the nine-dash line was "[I]n brief, a dispute over the source and existence of maritime entitlements does not 'concern' sea boundary delimitation merely because the existence of overlapping entitlements is a necessary condition for delimitation". ${ }^{42}$ The Tribunal reasoned that since this was a dispute over the maritime entitlements generated by the various dispute features in the South China Sea, the dispute did not concern maritime delimitation. In relation to historic titles, the most crucial issue to determine jurisdiction under Article 298.1 of the UNCLOS, China claimed that the South China Sea belonged to it for a prolonged period. ${ }^{43}$ The Tribunal stated that this depended on the nature of historic claims and the scope of the Article 298 UnCLOS exception. However, the Tribunal stated that "[i]n the absence of a more specific indication from China itself, it necessarily falls to the Tribunal to ascertain, on the basis of conduct, whether China's claim amounts to 'historic title". ${ }^{4}$ The Tribunal determined that the Chinese claim did not involve title and following this did not fall under the scope of the exception under Article 298(1)(a)(i) ${ }^{45}$ Finally, the Tribunal declared that any rights China stipulated on the basis of historic title were "superseded ... by the limits of the maritime zones provided for by the [UNCLOS]".46

Problematic is that China propounds its international legal weight depending on its circumstances - whereas B.S. Chimni correctly observed that the UNCLOS was largely CIL and developed by the Western powers in their quest

submit argument and evidence in support of its own case. Proceedings before the Court call for vigilance by all". Very interestingly, one of the counsels in that case for Nicaragua was also the counsel of the Philippines, Mr. Paul S. Reichler.

Foreign Ministry Spokesperson Hua Chunying's Remarks on the Philippines' Efforts in Pushing for the Establishment of the Arbitral Tribunal in Relation to the Disputes Between China and the Philippines in the South China Sea, Ministry of Foreign Affairs of the People's Republic of China (Apr. 26, 2013), https://www.fmprc.gov.cn/mfa eng/xwfw_665399/s2510_665401/2535_665405/t1035577.shtml.

42 South China Sea Arbitration, supra note 31, If 204.

43 See Masahiro Miyoshi, China's "U-Shaped Line" Claim in the South China Sea: Any Validity Under International Law?, 43 OCeAn Development \& International LaW 1 (2012); Zhiguo Gao \& Bing Bing Jia, The Nine-Dash Line in the South China Sea:History, Status, and Implications, 107 American Journal of International LAW 98 (2013).

44 South China Sea Arbitration, supra note 31, If 206.

45 See id. 1229.

$46 \quad$ Id. 9262. 
for colonial expansion, exploitation and pillage ${ }^{47}$ China picks and chooses the customs of the West to suit its own power aspirations. ${ }^{48}$ Indeed it is true that European landlocked states had little to nothing to contribute to the development of the laws of the sea. However, isn't it also true that on the flip side a few Western states had dominated the creation and further development of the law of the sea that morphed into the UNCLOS? ${ }^{49}$ The UNCLOS is another evidence that law based on Western knowledge leads to the entrenching of the power paradigm for the global power in Asia, namely China. To this end, it needs to be reconsidered that development of a customary law of the community is the way for a true custom of the peoples. It is accepted at the same time that Asian state practice under the UNCLos has evolved and taken ownership - Asian states are invoking dispute settlement mechanisms and are trying to reinterpret parts of the UNCLOS to give effect to their regional aspirations. To this end, Shunji Yanai held that:

It could be understood that Asian States, which were considered to be reluctant to use judicial or arbitral dispute settlement procedures, are slowly changing their attitude toward accepting third party adjudication for the settlement of disputes, thus contributing more actively to the development of international law. ${ }^{50}$

And yet, there is no uniform Asian state practice, and it is rather the opposite: CIL is used under different interpretations and narratives by Asian states to pursue their sovereign goals in the region - dispute mechanisms are there to propound those ambitions. Judge Xue Hanqin writes:

Asia's attitude to international law, if deemed ambivalent, is deeply rooted in its history. As is rightly pointed out, that only offers a partial explanation. More relevant is the contemporary practice of international law, particularly of the Western world. Asian States are more sensitive of delegating sovereignty, not because they are ambivalent of international

\footnotetext{
47 See Chimni, supra note 17.

48 See Mark J. Valencia, US 'Picking and Choosing' from the Law of the Sea, EAST Asia Forum (Aug. 17, 2018), https://www.eastasiaforum.org/2018/08/17/us-picking-and-choosing -from-the-law-of-the-sea.

49 See Alan Boyle, EU Unilateralism and the Law of the Sea, 21 The International Journal of Marine And CoAstal LaW 15 (2006).

50 Judge Shunji Yanai, Keynote Speech at the International Symposium on the Law of the Sea, The Rule of Law in the Seas of Asia: Navigational Chart for the Peace and Stability (Feb. 12-13, 2015) (transcript available at https://www.mofa.go.jp/files/oooo74503.pdf).
} 
law, but because they do not believe that international law as thus advocated and practiced would protect their fundamental rights and interests. In many a case, their under-participation is not a matter of willingness, but capacity to influence. To be a meaningful rule-maker, Asia still has a long way to go. ${ }^{51}$

This begs the question: how can a law based on opinio juris communis overcome such divergent interpretations, serve the goal of a common Asian practice and enable the view of the community to proliferate?

\section{What is Opinio Juris Communis?}

\subsection{Generating the Law of the Community}

The law of the community can be deduced from the United Nations General Assembly's (UNGA) growing importance as a centre for the concerns of the Global South, as it represents the vast majority of the members of the UNGA. To this end, resolutions of the UNGA have morphed into customary international law, as it represents the voices of the world community. ${ }^{2}$ Is there perhaps room for the perception of instant customary law? ${ }^{53}$ Can the UNGA turn into a law-making entity within the United Nations, a forum of global conscience? Is there something to be referred to as opinio juris communis? The UNGA is a body from which a sense of global consciousness has to evolve.

However, while Article 2.1 of the United Nations Charter stresses the sovereign equality of states in international law, it can be questioned if there is such. Formal equality must be complemented by substantive equality, as it needs to meet the requirements of justice or fairness. ${ }^{54}$ Substantive equality necessarily implies that existing inequalities in inter-state relations must be taken into account in all decision-making processes at the international level. Consequently, in such situations the realization of substantive equality brings about the need to treat unequal states unequally. Thus, differential treatment

51 Xue Hanqin, An Asian Perspective, Opinio Juris (Jan. 18, 2017), http://opiniojuris.org/ 2017/o1/18/an-asian-perspective.

52 M.C.W. Pinto, Responsibility to Protect ('R2P'), in Asian Approaches to International LaW and the Legacy of Colonialism: The law of the Sea, Territorial Disputes and International Dispute Settlement 146 (Jin-Hyun Paik et al. eds., 2014).

53 Bin Cheng, United Nations Resolutions on Outer Space: "Instant" International Customary Law?, 5 The Indian Journal For International LAW 23, 36 (1965).

54 See Ulrich Beyerlin, Bridging the North-South Divide in International Environmental Law, 66 ZAöRV 259, 272 (2006). 
can prove to be the only means of ensuring substantive equality that is part of international justice.

\subsection{Fostering a Law of Community}

The right to self-determination, a right that was invoked by the Global South as a floating international legal device to accelerate the decolonisation process, was recently declared by the ICJ as customary international law. To this end Muttucumaraswamy Sornarajah writes that:

Unlike existing norms of international law which were ascribed to the conduct of states and as constituting customary principles, most of the new norms were articulated by Third World states on behalf of peoples and were asserted on the basis of justice. A core sense of justice animated the norms that were proposed. The equality of people and the ending of domination of one people by another was the basis of the principle of self-determination. ${ }^{55}$

The ICJ had held in the Chagos Advisory Opinion that:

[T] he nature and scope of the right to self-determination of peoples, including respect for the national unity and territorial integrity of a State or country, were reiterated in the Declaration on Principles of International Law concerning Friendly Relations and Co-operation among States in accordance with the Charter of the United Nations. ${ }^{56}$

This Declaration was annexed to General Assembly resolution 2625 (XXv) which was adopted by consensus in 1970. "By recognizing the right to selfdetermination as one of the "basic principles of international law", the Declaration confirmed its normative character under customary international law".57 The idea of the opinio juris communis, in this vein, is based on the premise that individuals, indigenous groups, civil society actors and nongovernmental organisations are taking on a greater role in the formation of the views and opinions on international legal relations and matters. B.S. Chimni writes in his widely considered and discussed article that:

\footnotetext{
55 See Muttucumaraswamy Sornarajah, Power and Justice: Third World Resistance in International Law, 10 Sybil 19, 20 (2006).

56 Press Release, International Court of Justice (ICJ), Legal Consequences of the Separation of the Chagos Archipelago from Mauritius in 1945, at 4, ICJ Press Release No. 2019/9, (Feb. 25, 2019).

Id.
} 
A postmodern doctrine would therefore go further and look at the weight of resolutions through the prism of the global common good. Those resolutions that reflect opinio juris communis and further the goals of international human rights law and associated jurisprudence would be considered to have binding effect. In operative terms this would mean that in instances where a qualifying resolution is adopted by an overwhelming majority of votes, undue weight will not be attached to opposing votes if it furthers the cause of global justice. ${ }^{58}$

The development of the persistent objector doctrine is one which evolved in the 1970s to deal with the independence of Third World states and its effects on the international legal order, when "Western States feared losing control over the development of customary law". 59

In this sense, the doctrine would be a sort of "counter-reformation" by the West against the attempts of Third World countries to use their majority in multilateral organizations to reshape international law, or, in other words, an exhaust valve, so that traditional states would not be bound by the norms put forward by the Third World. ${ }^{60}$

To this end, the Republic of Korea remarked that the role of persistent objector was one that needed more clarification and elaboration after the ILC's identification of customary international law in its 67 th session of the International Law Commission in $2015 .{ }^{61}$

\section{Conclusion: Towards a New Custom}

For some, international law is best created exclusively through treaties, as to which states can opt out by non-action, simply by declining to ratify the instrument. So long as customary norms take many decades to ripen into

58 Chimni, supra note 17 , at 42.

59 Patrick Dumberry, Incoherent and Ineffective: The Concept of Persistent Objector Revisited, 59 The International and Comparative LaW Quarterly 779, 783 (2010).

6o George Rodrigo Bandeira Galindo \& César Yip, Customary International Law and the Third World: Do Not Step on the Grass, 16 Chinese Journal Of International LaW 251, 267 (2017).

61 Comments by the Republic of Korea, 7oth session of the International Law Commission (2018), https://legal.un.org/docs/?path=../ilc/sessions/7o/pdfs/english/icil_republic_of_ korea.pdf\&lang=E (last visited May 5, 2020). 
law, customary international law does not seem threatening. But it is another matter, if customary law can be formed within just a few years and is deemed binding on the states that have not affirmatively manifested their persistent objection. In such cases, they may fear the concept of law formation that appears more revolutionary than evolutionary. At the same time, the case studies of Grotian Moments demonstrate international recognition that customary international law must have the capacity in unique circumstances to respond to rapidly evolving developments by producing rules in a timely and adequate manner. They also demonstrate that not every momentous technological, geo-political or societal change results in accelerated formation of customary international law. There are complaints about overarching positivism. They argue for the creation of regional international courts and the prioritisation of legal certainty. It could be thought of as invoking and considering regional customary laws and regional general principles, seen in their common cultural tradition. ${ }^{62}$ But most importantly, it is about democratising CIL, given all its nuances, narratives and visions of the world, to make CIL a reflection of the law of the peoples. There is the assumption by those scholars of international law, mostly representing the Eurocentric vision of international law, that customary international law exists also for the newly independent states, as a gift from state practice of Western states. It is argued that these states, civilised in their history, were caretakers for the development of an international legal infrastructure. This needs and has to be refuted. Anghie and Ghatii write that:

Customary international law (CIL) is in many respects the foundation of international law. It comprises the principles that govern international relations even in the absence of a treaty, and is one of the means by which states register changes in the international system and represent them as law. It is understandable, then, that CIL has been the subject of intense and extensive theorizing, and that the most distinguished international lawyers, members of the International Law Commission, and the International Law Association have devoted so much time to its study and systematization. While cIL has traditionally been dominated by the West, scholars from the former Soviet Union and the non-European world have emerged to formulate their own distinctive views on CIL, seeing it as a Western invention designed to further Western interests. ${ }^{63}$

62 Andreas Buss, The Preah Vihear Case and Regional Customary Law, 9 Chinese Journal Of International LAW 111, 126 (2010).

63 Antony Anghie \& James Gathii, Introduction to the Symposium on B.S. Chimni, "Customary International Law: A Third World Perspective", 112 AJIL Unbound 29o, 290 (2018). 
The social order of property, propriety and power has to be radically revised. That is without question. The issue is what must be the strategy, the tactics and the way forward to a place that is not what we have now. The Global South is a place of great struggle and of various tactics and strategies experimented with on the streets and in the halls of government. Individual state consent cannot be regarded as the sole source of law creation and obligation, as it was stated in the Lotus case. ${ }^{64}$ Rather there needs to be the shift towards a type of international democratisation of international law, in which a greater reflection of the international community is necessary. ${ }^{65}$

64 The Case of the S.S. Lotus (Fr. v. Turk.), 1927 P.C.I.J. (ser. A) No. 10 (Sept. 7).

65 Hilary Charlesworth \& Christine Chinkin, The Boundaries of International Law: A Feminist Analysis, 95 The American Journal of International LaW 459 (2001). 